DOI: $10.1515 / \mathrm{rpp}-2016-0002$

Doctor of Pedagogical Sciences, Associate Professor, NATALIYA SAVOTINA Institute for the Study of Childhood, Family and Upbringing of Russian Academy of Education, Russia Address: 5/16 Makarenko St., Moscow, 105062, Russia E-mail: nasa-amigo@rambler.ru

\title{
THE POTENTIAL FOR DEVELOPMENT OF RUSSIAN YOUTH SOCIAL ACTIVITY
}

\begin{abstract}
The article deals with scientific and applied topicality of studying the problem of children and youth social activity. Spheres of social activity display in European tradition, in particular, the European Charter, Great Britain, have been revealed. Comparative analysis of understanding the essence of such a phenomenon in Western theories and scientific pedagogical thought in Russia has been given. The changes occurred in the context of the analysis of the notion during last decades and connected with the development of volunteering, motivation and forms of youth services have been emphasized. The most important tasks in developing social activity of Russian youth have been stated. Different scientific approaches to studying the notion of "social activity" enriching its characteristics have been analyzed. Based on the analysis of results on the organized events the drawbacks, neglects and causes of poor quality of working on the development of youth social activity have been shown. The experience in choosing activities and technologies demonstrated by teachers and pupils from different regions of Russia has been presented. Theoretical analysis of foreign and domestic experience in education has enabled to offer suggestions for the expansion of pupils and students' social activity in the frame of different models presenting a wide scope for mastering and developing social competency of children and youth. These models have become the foundation for creating a general algorithm for the expansion of children and youth social activity. Pedagogical conditions and perspective directions for solving the problem of social activity development have been outlined in the article.
\end{abstract}

Key words: social activity, technological potential in education, models of social activity development, Russian youth.

\section{INTRODUCTION}

Today, social activity is included into the discourse of the rising generation competitiveness enhancement and is considered as a factor of life quality. Young people have always acted as a social group, whose excessive activity has been taken under special control. Therefore, social activity, on the one hand, can be considered in the context of remonstrances and social instability. On the other hand, young people can provide the transmission of public relations and act as a carrier of social innovation, whereby the increase of youth social activity in unstable periods becomes one of the conditions of search for new forms of social organization (Иваненков, Кострикин, 2007).

Scientific and applied relevance of studying children and youth social activity is especially important in the context of such phenomena as youth unemployment, the inequality of "starting capital" while entering life, different opportunities of access to sociocultural resources, social apathy, etc. All these require an adequate assessment of inclusion 
of youth into social reality, identification of modern educational technologies potential for the development of social activity.

\section{THE AIM OF THE STUDY}

The aim of the study is to identify the potential of modern educational technologies for the development of children and youth social activity.

\section{THEORETICAL FRAMEWORK AND RESEARCH METHODS}

The study was based on retrospective analysis of changes in understanding of the term "social activity": the connection of the concept with the possibility of free choice (I. Cohn, B. Grushin, B. Kelly, N. Mamardashvili, G. Shchedrovitskii, etc.); the relationship of the social environment, personal activity and consciousness (L. Bueva, V. Lektorsky, K. Lyubutin); the method of inclusion in public relations (M. Kagan, V. Tugarinov); pedagogy of communication (A. Mudrik). In the works of the last decade (E. Kipriyanova, L. Nikitina, L. Novikova, I. Sizemskaya, S. Tatarskii, B. Titov, A. Walicki) problems of social activity are largely associated with problems of socialization.

The aim of the study was gained by using the methods of comparative analysis, experience analysis, questionnaires, interviews, longitudinal observation.

\section{RESULTS}

European tradition connects youth social activity, first of all, with the participation of young citizens in public life at local and regional levels. The spheres of social activity display can be various: education, social protection, sport, culture, employment, housing, transport, health, intercultural communication, the protection of youth rights, etc. The European Charter, as a measure for the development of youth participation in public life, includes the arrangement of special training programs and workshops, creation of information environment, promotion of youth participation in the media, support of youth projects and volunteer initiatives. A special role in the Charter consists in promoting youth organizations and self-governing groups, structures of self-government (youth parliaments, councils, etc.). For the implementation of such ideas in European countries there are used various technologies and non-formal education programs. In Germany training programs for young activists are accompanied by support for their mobility, giving a special young leader card (Jugend Leiters Karte - JuLeiKa), offering discounts at cultural and sport institutions, transport, stores. In the UK there is a program called "The prize of the Duke of Edinburgh", according to which the participant must meet the specific requirements for each of four directions (help and service to others, expeditions (research), skills and physical improvement), registering its completion in a special diary. Assistance in this work is provided by mentors, i.e. teachers and professionals working with young people at schools, youth clubs and youth organizations. This program focuses not so much on competition with others but on the competition with yourself, overcoming yourself and self-improvement.

According to Western theories, social activity acts as an entrepreneurial activity that is motivated by stimuli in the form of material and upward mobility support.

In the scientific literature of the Soviet period the social activity of young people was considered as a political activity (participation in elections, membership in public associations, etc.) or cultural activity (belonging to subcultural communities, informal youth associations, movements, etc.). In recent years, due to the development of volunteerism, the context of social activity analysis in scientific research has changed: the number of works analyzing the motivation of youth participation in volunteering, principles and forms of youth service has increased. Youth activism in this context is, first of all, the opportunity to experience other behavioral, situational and social practices in a more 
vibrant, game, "quick" forms. It is a kind of included social skills teaching when it is important not what you do but how you do it, and how much you are responsible for your actions (Новое литературное обозрение, 2008).

In Russia the most important tasks for the development of youth civic engagement include: the sharing of effective models and forms of youth participation in the administration of public life; the involvement of young people into the activities of government bodies and authorities; encouragement of young people to participate in project and research activities; promotion of youth participation in public-political life; attraction of young people to the election process; support of youth public organizations and associations; involvement of young people into international projects on training of public associations leaders.

Analysis of the results of ongoing activities on development of children and youth social activity gives reasons for identification of the errors that affect its performance:

- there are not any new, exciting forms of initiatives realization due to weakness motivation of the young people;

- sponsoring youth programs appeals to individual activity rather than stimulation of group action and activity of youth groups;

- the activity of the youth structures in the authorities is usually decorative in nature, presenting the model of "sandbox" in which young people are allowed to "play", not being allowed to discuss and resolve serious problems;

- there is no demonstration of youth participation practices, containing elements of novelty, creativity, causing public interest and new supporters in social media;

- there is no coordination of youth policy with other areas of public policy that leads to a certain isolation of youth issues;

- activities planned for implementation do not always correspond to the objectives of the programs (Филимонова, Ведехин, 2012).

In the system of different sciences the concept of "social activity" is treated on the whole, as a conscious, purposeful interaction of the individual and the society. In philosophy social activity is treated as a particular form of interaction of the agent with the environment, the special status of any activities that are characterized positively. In psychology it is the view of the personal nature as a system of actions, needs and motives of behavior when the activity is a complex characteristic, which is expressed through its relation to activities. In pedagogy the notion of "social activity" is considered in various aspects: it is a superior quality in the characteristics of the person as a subject of social relations; the measure of existence of a personal social capacity; responsible and committed attitude to work, society, spiritual and public life (Баскаков, Соколова, 2008).

The approaches of different sciences enrich the concept of "social activity", contributing to their own essential characteristics. Philosophical view on social activity enriches the knowledge about the extent of the individual involvement in public life by characteristic of both internal and external vital positions in life of the individual. So, according to M. Elyutina, the inner side presents the socio-psychological components needs, interests, value orientations, attitudes and reflects the assimilation of the individual's objective activity, his/her attitude to it in the form of inner readiness, predisposition, certain value orientation. The external, objective side of life position acts as a social fact; it is found in practical actions and reflects the real capabilities of the objective world. Philosophers supplement the criteria of active life position formation with such qualities as ideological belief, social responsibility, conscientious attitude to the public debt and practical effects (Елютина, 1984). 
In his study V. Markin concluded that social skills and appropriate action provide the opportunity to judge the degree of a person's social maturity. The researcher selects dominant, nuclear relations, defined by public relations and which are always socially typical: attitudes towards society, other people, work, environment, material and spiritual monuments of history, to self. "Active face" of the person is manifested in the process of solving social problems. Everyone obtains the collective experience of the society, political principles and moral norms, i.e. realizes the essence and content of social relations, his/her own place in them, develops his/her own life concept and implements it with a different degree of activity in the society (Маркин, 1989).

An important aspect of the social field as a means of children and youth social adaptation was marked by G. Filonov. Self-assertion and self-realization in the social environment, according to the scientist, can be a means of society improvement. Different societies have different capabilities, but every society always has its internal reserves, its controlled pedagogical potential, revealing most of all in the practice of socially useful activity (Филонов, 1995).

Modern sociologists (G. Andreeva, L. Bueva, I. Kon) for the characterization of social activity assign an important place to the connection of social roles with certain activities. Thus, according to I. Kon, a social role itself does not determine the activities and behaviors of each specific carrier. To do this, it must be internalized. "An internalized role is an internal definition of the individual's social status and his/her attitude to this position and duties" (Маркин, 1989).

Reasoning logic of V. Slobodchikov and E. Isaev leads to interesting conclusions. In their view, people can/cannot perform social roles as they want. Through the free choice of social roles they realize the democratic principle of freedom (Слободчиков, Исаев, 2005).

Y. Gippenreiter comes to such conclusion: "In the course of mastering and performing roles, firstly, there are new motives, and secondly, there is their subordination, and thirdly, there is change in belief systems, values, ethics and attitudes" (Гиппенрейтер, 1996).

A. Makarenko's idea of "responsible dependence" and establishing conditions for such development are still meaningful for social activity education. V. Sukhomlinsky humanized the creation of such conditions, considering that the most important task is to develop the child's ability to feel the heart of another person, and this is expressed through the actions in the name of another and care about him/her.

It should be noted, that the importance of social activity, which is manifested in social work, has long been perceived as an axiom by teachers, but the application of this medium to social practice has difficulties in content, organizational and financial ways.

A significant analysis of scientific literature allowed us to determine its position, according to which, social action is seen as a desire and ability to act in the implementation of positive social goals, integrative quality, which characterizes the measure of intensity of public activity aimed at the improvement of the society and people in this society. The effectiveness of the process is especially high when while entering the society conditions for active perception of social values are created on the basis of the emotional responsiveness development, emotional restraint and psychological isolation are overcome as well as the forming of values occurs not only for the sake of self-affirmation, but also because we care "about others". Considerable ingenuity in the choice of activities and technology is shown by teachers and pupils of schools in different regions of Russia:

-Poems on wheels "Tram poetry" (Ekaterinburg);

-School emergency (school No 1, Yubileynyi, Moscow region);

-Alley of love (Ufa) / the Boulevard of love (Tyumen); 
-Intellectual competition of innovative scientific works "City for people" (traffic

-Present children with fairy-tales! (pupils - orphanage children);

-Surprises from Couture (models competition on the school podium);

_"No drugs!" Exhibition, poster and collage competition;

-Non-smoking class (a written commitment for a certain period) (St. Petersburg);

-Unemployed youth for veterans (the employment center signs an agreement with the administration of schools on nursing the disabled, landscaping, etc.) (Ryazan);

-The museum of bad habits "Be a friend to your health!" (defense and accumulation of pupils' projects) (Syktyvkar);

-Children reconciliation service (pupils-volunteers act as peacekeepers) (Volgograd);

- "From the language of hostility to the language of peace" (Clean up the city from extremist captions campaign) (Perm);

-Charity team "Timurovtsy" (the employment center) (Samara region); services) (Perm)

- "Pure generation campaign" (city marches, trainings, relay races, counseling

Involvement of students into different types of social activity opens wide perspectives in educating a socially active personality, whose proactive attitude is manifested in the integrated unity of the three semantic units: towards self as a subject of moral, legal, political relations; active and independent activity in various spheres of life; others (society, community). Analysis of foreign and domestic experience in education has helped us identify opportunities to enhance the social activity of pupils and students at education institutions in the frames of following: a subject model; the "community service" model (social mutual aid, social service); an institutional model.

1. The subject model of children and youth social activity development involves the development of social competency while studying academic disciplines of the socioeconomic, political, legal, pedagogical complex. Priority of such a model consists in gaining knowledge and skills in comprehending the information in the field of democratic state and civil society building, the ability to analyze this information and compare it with the realities of life. This model enables to highlight the direction, when the development of theoretical texts is accompanied by review and analysis of information originating from this or that sphere of social practice: human rights, economic and social policy, jurisprudence. The effectiveness of this model is undoubtedly enhanced by the use of interactive teaching methods: role-playing games, discussions, modeling, designing, etc. When implementing this model it must be taken into account that the knowledge-based approach in the framework of the subject model is the process of learning to search for competent independent decisions in social practice, liberating from the stereotypes and involving intellectual efforts. Such intellectual efforts are important, because they create the conditions and prerequisites for the practical participation in real social projects.

2. The "community service" model of social solidarity is based on a combination of academic and extracurricular activities, involving students in solving community problems. The experience of applying to the system of social mutual assistance in educating social competency of young people is well-known in the Western World. Young people with different levels of education within the framework of extracurricular educational work are actively involved in various social activities, are encouraged to watch the implementing of specific social programs, receiving relevant general information within the framework of academic disciplines. Modern society presents a wide field for the development of children 
and youth social competency. Attending socio-pedagogical centers, social shelters and centers for social rehabilitation widens the social space of educational activities. Feeling the urgency of social realities (homelessness, poverty, search for jobs, social protection, security, health protection and preservation, socio-demographic problems, etc.), a young man enters the social situation of development, transforming the space of connections and relationships between participants. Increased awareness of pupils through obtaining real experience of the basic social institutions activities creates a semantic unit, which is acquiring personal meaning in social situations. The model is focused on encouraging children and young people to participate in specific activities rather than being only knowledge-based (excursions, study, etc.). We distinguish such prior objects of social space as orphanages, specialized schools, social centers and shelters, museums, military-patriotic clubs, etc. Involvement into the system of social mutual aid is a continuous process, taking place during all years of study with the differentiation of social sustainability: from the spiritualcultural realities (participation in the improvement of the area, reconstruction of cultural and religious monuments) to the development of more complex forms of social activity (participation in elections, charity), as well as the gaining of teamwork skills, conflict resolution skills, intergenerational communication skills, mastering of various social roles.

3. The institutional model of children and youth social activity expansion. This model is considered to be the practical framework for the development of key social competencies. The model assumes the following scenarios for the development of social, political and legal competencies at school:

Scenario 1. At school (university) elements of civil life are modeled (recreated) through public self-government.

Scenario 2 . The basic elements of education community activities organization (learning style, the system of relationships, the nature of educational achievements evaluation, the style of social organization) are coordinated in compliance with democratic values.

Scenario 3. Mode of school (university) community. The structure of the educational space is built in such a way as to ensure the realization of the first two scenarios.

Scenario 4 consists in transforming a school (university) from the local educational space into the center of public and cultural relations, establishing partnerships with other educational organizations, institutions of culture, health, social protection, local companies.

The choice of a particular model for the social activity field expansion, in our opinion, should not be determined by subjective factors. For example, the existence of a system having developed connections with the objects and social institutions creates a basis for the implementation of the social solidarity model, and a team of strong leaders at schools ensures the development of institutional models.

The abovementioned models allow us to propose a general algorithm for the expansion of children and youth social activity (see Table 1):

Table 1

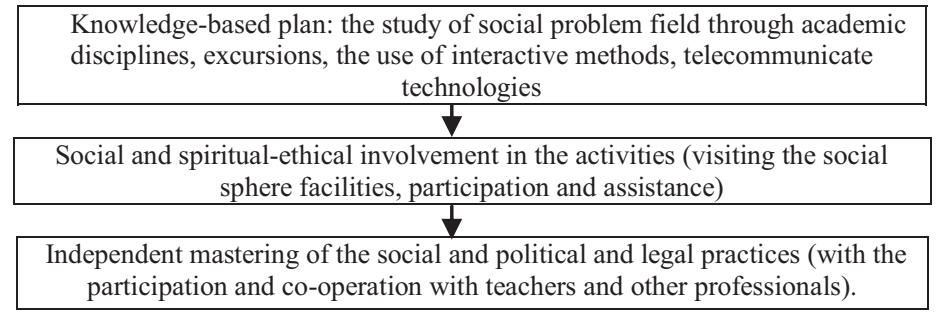




\section{CONCLUSIONS}

Social activity of personality develops optimally when the following pedagogical conditions are observed:

- when the involvement into social activities is supported by the development of an active life position and the system of orientation towards socially significant values;

- when school (student) groups are an integral (where the integrity does not undermine the autonomy and individuality), evolving and developing system, providing comfortable relationship between all members;

- when applied social and pedagogical technologies mobilize the positive emotional attitude to solving problems as self-realization in social activity and readiness to participate in realization of society needs;

- when the activities of children public associations are linked to other institutions of socialization and stimulate extra activities of pupils in different spheres of social life.

The results of the research allow us to offer the perspective directions to resolve the problem of social activity development: use of youth social activity to overcome civil infantilism, prevention and neutralization of factors of youth aggressive behavior.

\section{REFERENCES}

1. Баскаков, А. М., Соколова, Ю. Г. (2008). Спутник исследователя по педагогике [Guide for the Researcher in Pedagogy]. Челябинск : ООО «Полиграф-Мастер», 600 p. (in Russian).

2. Гиппенрейтер, Ю. Б. (1996). Введение в общую психологию. Курс лекиий [Introduction into General Psychology. Lecture Course]. M., 336 p. (in Russian).

3. Елютина, М. Э. (1984). Методологические проблемы формирования активной жизненной позиции личности [Methodological Problems of Personal Active Life Position Forming]. Abstract of thesis for PhD in Pedagogical Sciences. Saratov, 23 p. (in Russian).

4. Иваненков, С. П., Кострикин, А. В. (2007). В фокусе - молодежный активизм [In Focus - Youth Activism]. In : Андреева, Ю. и др. (Eds.), Поколения.net: Хроники событий [Generations.net: Course of Events]. Ульяновск : Издательский центр Ульяновского государственного университета, pp. 76-80 (in Russian).

5. Маркин, В. Н. (1989). Жизненная позииия личности: Идеологический и соииально-психологический аспекть [Personal Life Position: Ideological and SocialPsychological Aspects]. M., 173 p. (in Russian).

6. Новое литературное обозрение [New Literary Review]. (2008). Ростки политического: молодежный активизм в Германии и России [Political Beginnings: Youth Activism in Germany and Russia]. Неприкосновенный запас [Reserved Supply], No 5 (61). Retrieved 25.10.2015 from : http://www.nlobooks.ru/rus/nz-online/619/1115/.

7. Слободчиков, В. И., Исаев, Е. И. (2005). Основы психологической антропологии. Психология человека: Введение в психологию субъектности [Fundamentals of Psychological Anthropology. Human Psychology: Introduction into Psychology of Subjectivism]. M., 384 p. (in Russian).

8. Филимонова, Н. М., Ведехин, А. Ю. (2012). Идентификация проблем реализации молодежной политики [Identification of Youth Policy Realization Problem]. Российское предпринимательство [Russian Entrepreneurship], No 18 (240), pp. 30-34 (in Russian).

9. Филонов, Г. Н. (1995). Сочиальная педагогика. Управляемый потенциал и прикладные функиии [Social Pedagogy. Guided Potential and Applied Functions]. M. : ЦСП РАО, 23 p. (in Russian). 